\title{
Level of Math Problem Solving Proficiency Grade V SDN 2 Kalirejo on Fractional Story Problem
}

\section{Marita Cahya Purnama, Tri Yuniantari Redyoningrum, Liftahul Sekar Aji, Moh Salimi}

Universitas Sebelas Maret

marita.20cp@student.uns.ac.id

\section{Article History}

accepted 24/09/2019

approved 01/10/2019

published 01/12/2019

\begin{abstract}
In mathematics, students' ability to solve problems is very much needed. Every student has different abilities. For this reason, it is necessary to conduct a research in order to find out the students' abilities in solving problems in mathematics, especially in fractional material. In researching, quantitative description is the method chosen by the researcher. In this study using a research instrument in the form of a test to measure students' ability to solve mathematical problems and conducted interviews. Data analysis of the results of mathematical tests about solving fractions of fifth grade students at SD Negeri 2 Kalirejo is in the high category. This is evident from the results of tests at $S D$ Negeri 2 Kalirejo that included in the high category were $61.29 \%$, moderate were $23.80 \%$ and the low and very low categories were $12.89 \%$.
\end{abstract}

Keywords: Mathematics, Fractions, Problem Solving

\begin{abstract}
Abstrak
Dalam pelajaran matematika kemampuan siswa untuk menyelesaikan soal sangat dibutuhkan. Setiap siswa memiliki kemampuan yang berbeda. Untuk itu perlu diadakan sebuah penelitian agar dapat mengetahui kemampuan siswa dalam pemecahan masalah pada mata pelajaran matematika khususnya materi pecahan. Dalam meneliti,deskripsi kuantitatif adalah metode yang dipilih oleh peneliti. Pada penelitian ini menggunakan instrumen penelitian berupa tes untuk mengukur kemampuan siswa menyelesaikan soal matematika serta dilakukan wawancara. Analisis data hasil tes matematika tentang pemecahan masalah pecahan siswa kelas V SD Negeri 2 Kalirejo tergolong pada kategori tinggi. Hal tersebut terbukti dari hasil tes di SD Negeri 2 Kalirejo bahwa yang masuk dalam kategori tinggi sebesar 61,29\%, sedang sebesar $23,80 \%$ serta kategori rendah dan sangat rendah sebesar $12,89 \%$.
\end{abstract}

Kata Kunci : Matematika,Pecahan, Pemecahan Masalah

Social, Humanities, and Education Studies (SHEs): Conference Series https://jurnal.uns.ac.id/shes 


\section{PENDAHULUAN}

Pendidikan di sekolah dasar pada era revolusi industri 4.0 ini lebih menekankan pada kemampuan pemecahan masalah siswa. Dalam Permendikbud No 21 tahun 2016 menyatakan kemampuan memahami masalah, merancang model, menyelesaikn dan menafsirkan solusi adalah salah satu tujuan pembelajaran matematika dalam hal pemecahan masalah. Pendapat lain menurut (Harmini, 2014) tujuan pembelajaran matematika adalah siswa dalam kehidupan sehari-hari dapat diarahkan untuk menyelesaikan masalah.

Dahar mengungkapkan bahwa pemecahan masalah berarti menggabungkan pengetahuan sebelumnya yang dimiliki dengan pengetahuan baru yang mana bukan keterampilan genetik (Juanda, 2014). Siswono menyatakan bahwa pemecahan masalah yakni cara seseorang mengatasi masalah ketika ketika suatu metode jawaban belum tampak jelas (Ana, 2012). Pemecahan masalah juga berarti suatu usaha mencari jalan keluar dari suatu kesulitan, bertolak dari pengetahuan sebelumnya dan ia juga dapat menemukan kombinasi berbagai konsep dan kaidah yang tepat serta mengontrol proses berpikirnya (Anwar \& Amin, 2013). Sehingga pemecahan masalah dapat dikatakan pola pikir individu atau seni dalam mencari jalan keluar dari setiap masalah yang muncul.

Branca mengemukakan pentingnya kemampuan pemecahan masalah matematika sebagai berikut: (a) pemecahan masalah merupakan tujuan umum pengajaran matematika, (b) pemecahan masalah yang meliputi metode, prosedur, dan strategi merupakan proses inti dan utama dalam kurikulum matematika, dan (c) pemecahan masalah merupakan kemampuan dasar dalam belajar matematika (Tina, 2016). Dikutip dari Thyeadi Tungson yang menuturkan bahwa Membekali pelajar dengan penguasaan terhadap penyelesaian soal-soal yang menuntut kemampuan berpikir tingkat tinggi merupakan suatu keharusan. Salah satu aspek yang diajarkan pada pembelajaran matematika di sekolah dasar yang sesuai dengan tahapan perkembangan anak adalah materi pecahan.

Karso menyatakan bahwa dalam menyelesaikan masalah soal-soal matematika berbentuk kalimat cerita siswa dituntut untuk memiliki pemahaman konsep dan keterampilan matematika, memahami masalah soal tersebut serta membuat rencana menetapkan apa yang diminta dari data yang diketahui (Irawan, 2011). Raharjo (2011: 8) menyatakan bahwa soal cerita yang terdapat dalam matematika merupakan persoalan-persoalan yang terkait dengan permasalahan-permasalahan dalam kehidupan sehari-hari yang dapat dicari penyelesaian dengan menggunakan kalimat matematika. Hudoyo menyatakan bahwa soal cerita merupakan soal jenis tertentu dalam matematika yang disajikan dalam bentuk bahasa atau cerita kehidupan seharihari (Auzar, 2013). Jadi, soal cerita adalah soal yang diungkapkan dalam bentuk cerita yang diambil dari pengamatan sehari-hari. Soal cerita tidak hanya diselesaikan dengan menggunakan rumus atau dengan gambar, melainkan soal cerita lebih ditekankan pada pemahaman suatu soal dan bagaimana cara menyelesaikannya.

Setiap siswa memiliki kemampuan intelektual yang berbeda-beda, hal ini dapat dilihat dari cara siswa menyelesaikan soal cerita yang diberikan. Musdhalifah menyatakan bahwa kesalahan-kesalahan yang muncul dalam proses pemecahan masalah seperti kesalahan fakta, kesalahan proses, kesalahan dalam memberikan kesimpulan, kesalahan perhitungan, hal ini disebabkan karena siswa kurang mampu memahami masalah yang diberikan serta kebiasaan siswa yang menyelesaikan masalah langsung pada prosesnya tanpa menuliskan yang diketahui terlebih dahulu (Porwanto, 2014). Dalam pemecahan masalah proses berfikir dilakukan secara sistematis dan ilmiah dimana terdapat langkah-langkah yang harus dilaksanakan. Salah satu langkah pemecahan masalah yang dapat digunakan adalah langkah pemecahan masalah menurut Polya yaitu (1) memahami masalah, (2) menentukan rencana strategi penyelesaian masalah, (3) menyelesaikan strategi penyelesaian 
masalah dan (4) memeriksa kembali jawaban yang diperoleh (Komariah, 2011). Berdasarkan berbagai uraian diatas dapat diketahui bahwa setiap siswa memiliki kemampuan intelektual yang berbeda-beda termasuk di SDN 2 Kalirejo.

Sehingga peneliti tertarik untuk meneliti bagaimana tingkat kemampuan pemecahan masalah siswa dan tingkat kemampuan setiap tahapan tes kemampuan pemecahan masalah siswa Kelas V SDN 2 Kalirejo pada soal cerita pecahan yang berjudul "Tingkat Kemampuan Pemecahan Masalah Matematika Siswa Kelas V SDN 2 Kalirejo Pada Soal Cerita Pecahan". Diharapkan penelitian ini dapat menjadi referensi bagi pembaca terutama para guru untuk dapat mengukur kemampuan pemecahan masalah siswanya.

\section{METODE}

Pendekatan deskriptif kuantitatif adalah jenis penelitian yang penulis pilih. Siswa kelas V di SD N 2 Kalirejo sebagai subjek dalam penelitian. Analisis hasil tes untuk mengukur kemampuan tingkat pemecahan masalah matematika adalah sumber data. Teknik analisis data menganalisis secara kuantitatif berdasarkan pendoman penskoran hasil tes menyelesaikan masalah soal pecahan. Dimulai dari menghitung rata-rata hasil persentase tiap tahap dan dikualifikasikan ke dalam empat kategori yaitu sangat rendah, rendah,sedang dan tinggi seperti dalam pedoman penilaian dari Suharsimi Arikunto(Purnamasari,2015) pada tabel berikut.

\begin{tabular}{cc} 
Kualifikasi Kemampuan Pemecahan Masalah Siswa \\
\cline { 2 - 2 } SKOR SISWA & KUALIFIKASI \\
\hline $0-10$ & SANGAT RENDAH \\
$11-20$ & RENDAH \\
$21-30$ & SEDANG \\
$31-40$ & TINGGI \\
\hline
\end{tabular}

Untuk memperkuat hasil penelitian maka dilakukan juga analisis kualitatif berupa hasil wawancara kepada siswa tentang tingkat menyelesaikan soal pecahan. Untuk menganalisis secara kualitatif menggunakan adaptasi dari Miles dan Huberman (Purnamasari,2015) denga tahapan mengumpulkan data, menyajikannya serta terakhir membuat kesimpulan.

\section{HASIL DAN PEMBAHASAN}

Dari data skor siswa yang diperoleh, rata - rata persentase skor setiap tahapan penyelesaian tes kemampuan memecahkan masalah disajikan pada tabel berikut.

\section{Rata - Rata Persentase Skor Tahapan Menyelesaikan Tes Kemampuan Memecahkan Masalah}

\begin{tabular}{clcc}
\hline No & Tahapan Penyelesaian & $\begin{array}{c}\text { Persentase Setiap } \\
\text { Tahapan }\end{array}$ & Kualifikasi \\
\hline 1 & Memahami Masalah & $83,59 \%$ & TINGGI \\
2 & Merencanakan Penyelesaian & $82,20 \%$ & SEDANG \\
3 & Menyelesaikan Masalah & $78,76 \%$ & RENDAH \\
4 & Pengecekan Kembali & $21,77 \%$ & SANGAT \\
& & & RENDAH \\
\hline
\end{tabular}

Hasil dari data di atas menunjukkan bahwa setiap siswa memiliki kemampuan pemecahan masalah matematis yang dapat dilihat dari setiap tahapan. Tahapan yang pertama memahami masalah diperoleh $83,59 \%$ dengan kualifikasi tinggi yang dibuktikan dengan hasil jawaban siswa pada tahap pertama menunjukkan bahwa 
siswa berhasil memahami masalah secara menyeluruh karena siswa tersebut sudah mampu menemukan jawaban dengan benar dan menuliskan keterangan diketahui/ ditanyakan serta siswa mampu mengetahui informasi atau permasalahan dengan lengkap dan menuliskan kesimpulan jawaban. Ketika diwawancara siswa memang telah memahami bahwa pengerjaan soal dengan menuliskan keterangan diketahui/ ditanyakan yang biasanya sudah diajarkan oleh gurunya sehingga tidak mengalami kesulitan dalam memahami soal. Berdasarkan hal tersebut, dapat dikatakan siswa telah mampu menguasai tahap memahami masalah dengan benar sehingga dikualifikasikan tinggi.

Sedangkan, pada tahapan kedua merencanakan penyelesaian diperoleh $82,2 \%$ dengan kualifikasi sedang yang dibuktikan dengan hasil jawaban siswa menunjukkan bahwa siswa sudah benar menggunakan penyelesaian dengan cara pecahan pengurangan dan menggunakan urutan penyelesaian yang sesuai. Menuliskan langkah penyelesaian ada namun terdapat beberapa siswa yang belum relevan atau jelas dalam menuliskannya tetapi mengarah pada jawaban benar atau menuliskan langkah penyelesaian tidak lengkap dan jawaban salah seperti belum ada kesimpulan jawaban. Ketika diwawancara mengapa penyelesaian ini menggunakan cara pengurangan kemudian siswa menunjukkan kata di soal yang menunjukkan bahwa soal ini menggunakan cara pengurangan berarti siswa memahami soal namun saat ditanya adakah langkah lain atau cara lain selain cara yang dipakai sekarang. Sebagian besar siswa tidak mengetahui cara lain namun terdapat juga siswa yang mengetahui cara lain. Siswa lebih memilih cara ini karena lebih mudah dipahami. Berdasarkan hal tersebut, sebagian siswa belum mampu merencanakan penyelesaian sehingga dikualifikasikan sedang.

Selanjutnya, pada tahapan ketiga menyelesaikan masalah diperoleh $78,76 \%$ dengan kualifikasi rendah yang dibuktikan dengan melihat hasil jawaban siswa menunjukkan bahwa siswa sudah menggunakan prosedur penyelesaian masalah yang sesuai namun sebagian besar siswa belum benar dalam menggunakan prosedur penyelesaian dan perhitungan yang salah sehingga menghasilkan jawaban yang salah adapun yang menggunakan prosedur penyelesaian dengan benar tetapi perhitungan salah/kurang lengkap. Ketika diwawancara mengapa memakai cara ini dan bagaimana langkah mengerjakannya, terdapat siswa yang kebingungan. Siswa hanya asal menduga tanpa dasar yang jelas. Hal ini termasuk kategori kesalahan manipulasi tidak langsung dimana jawaban benar diperoleh dengan menggunakan alasan yang tidak logis atau acak. Berdasarkan hal tersebut, dapat diketahui bahwa siswa belum mampu menyelesaikan masalah dengan prosedur yang baik sehingga dikualifikasikan rendah.

Selanjutnya pada tahapan keempat pengecekan kembali diperoleh $21,77 \%$ dengan kualifikasi sangat rendah yang dibuktikan dengan hasil jawaban pada tahap keempat pengecekan kembali menunjukkan kebanyakan siswa tidak menuliskan kesimpulan dan tidak melakukan pengecekan terhadap proses juga hasil jawaban dan hanya sebagian kecil siswa yang melakukan pengecekan terhadap proses atau hanya menuliskan kesimpulan saja tanpa melakukan pengecekan dan jarang sekali menuliskan kesimpulan serta melakukan pengecekan. Ketika diwawancara sebelum dikumpulkan dicek lagi atau tidak, kebanyakan siswa tidak melakukan pengecekan atau hanya dicek satu kali saja jarang yang berkali-kali dicek. Berdasarkan hal tersebut, dapat diketahui bahwa siswa sangat belum mampu melakukan tahapan pengecekan kembali dengan baik sehingga dikualifikasikan sangat rendah.

Penelitian lain dari Suci Ariani, dkk (2017) juga memperoleh data aspek memahami masalah memiliki kemunculan aspek tertinggi yaitu $89,63 \%$, kemunculan aspek merencanakan penyelesaian $63,7 \%$, kemunculan aspek menyelesaikan perencanaan $45,56 \%$, dan aspek mengecek kembali memiliki kemunculan terendah $16,11 \%$. 
Setelah itu, dihitung skor masing - masing siswa untuk kemudian dikualifikasi ke masing - masing tingkatan yaitu, tinggi, sedang, rendah dan sangat rendah. Berikut hasil tingkat kemampuan pemecahan masalah siswa kelas V SDN 2 Kalirejo dari data tes kemampuan pemecahan masalah matematika pada soal pecahan uraian ditunjukkan sebagai berikut :

Hasil kualifikasi skor siswa pada tes kemampuan pemecahan masalah SKOR SISWA Frekuensi matematika

\begin{tabular}{ccc}
\hline $0-10$ & 1 & SANGAT RENDAH \\
$11-20$ & 3 & RENDAH \\
$21-30$ & 8 & SEDANG \\
$31-40$ & 19 & TINGGI
\end{tabular}

Dari data di atas dapat dilihat bahwa siswa yang memiliki kemampuan pemecahan masalah pada kualifikasi tinggi sebesar $61,29 \%$. Hal ini dapat dikatakan bahwa sebagian besar siswa tersebut sudah mampu memahami dengan baik apa yang ditampilkan dari soal tes. Siswa yang memiliki kemampuan pemecahan masalah sedang sebesar $23,80 \%$. Sedangkan $12,89 \%$ siswa memiliki kemampuan pemecahan masalah yang rendah dan sangat rendah. Sedangkan siswa yang masih dalam kategori rendah dan sangat rendah memiliki pemahaman yang kurang baik dalam mengerti soal tes yang ditampilkan, memilih strategi penyelesaian, menyelesaikan masalah serta pengecekan kembali. Pernyataan ini juga berdasar pada hasil tes dan hasil wawancara siswa yang bersangkutan.

Penelitian lain yang dilakukan Romika (2014) mengungkapkan sebesar 62,46\% siswa memiliki kategori tinggi. Siswa yang memiliki kemampuan dalam pemahaman akan lebih mudah memecahkan masalah yang sedang diberikan dalam soal yang di diberikan.

\section{SIMPULAN}

Berdasarkan hasil penelitian tingkat kemampuan pemecahan masalah Matematika siswa kelas V SDN 2 Kalirejo pada soal cerita pecahan, diperoleh kesimpulan bahwa tingkat kemampuan pemecahan masalah siswa Kelas V SDN 2 Kalirejo Pada soal cerita pecahan termasuk kategori tinggi. Hal ini dapat dilihat dari kualifikasi kemampuan pemecahan masalah yang dimiliki siswa secara berturut-turut yaitu tinggi $61,29 \%$, sedang $23,80 \%$, rendah $9,67 \%$, dan sangat rendah $3,20 \%$ dan tingkat Kemampuan tiap tahapan tes kemampuan penyelesaian masalah siswa Kelas V SDN 2 Kalirejo Pada soal cerita pecahan pada aspek memahami masalah memiliki kemunculan aspek tertinggi yaitu sebesar 83, $59 \%$, aspek merencanakan penyelesaian 82,2 \%, aspek menyelesaikan perencanaan 78,76 \% dan aspek mengecek kembali memiliki kemunculan terendah 21,77\%. Bagi peneliti lain yang akan meneliti kemampuan pemecahan masalah maka hendaknya memberikan landasan pokok bahasan yang akan diujikan.

\section{DAFTAR PUSTAKA}

Anwar, S. \& Amin, S.M. (2013). Penggunaan Langkah Pemecahan Masalah Polya dalam Menyelesaikan Soal Cerita Pada Materi Perbandingan Di Kelas VI MI AlIbrohimy Galis Bangkalan. E-Pensa

Ariani, S., dkk. (2017). Kemampuan Pemecahan Masalah Matematika Siswa Pada Pembelajaran Matematika Menggunakan Strategi Abduktif-Deduktif Di SMA Negeri 1 Indralaya Utara. Surabaya. Jurnal Elemen Vol. 3 No. 1, Januari 2017, hal. $25-34$ 
Auzar. (2013). Hubungan Kemampuan Membaca Pemahaman dengan Kemampuan Memahami Bahasa Soal Hitungan Cerita Matematika Murid-murid Kelas 5 SD 006 Pekanbaru. Riau. Jurnal Bahas 8(1): 33-38.

Harmini. (2014). Matematika untuk PGSD. Surakarta: UNS Press.

Hasratuddin. (2013). Membangun Karakter Melalui Pembelajaran Matematika. Jurnal Pendidikan Matematika Paradikma, Vol 6, No. 2. , 130-141

Irawan, dkk. (2016). Faktor-Faktor yang Mempengaruhi Kemampuan Pemecahan Masalah Matematika: Pengetahuan Awal, Apresiasi Matematika, dan Kecerdasan Logis Matematis. Singaraja. Prosiding Seminar Nasional MIPA.

Juanda, dkk. (2014). Peningkatan Kemampuan Masalah dan Komunikasi Matematis Siswa SMP melalui Model Pembelajan Means Ends Analysis. Kreano. Diunduh dari: https://journal.unnes.ac.id/nju/index.php/kreano/article/view/3322/3651

Kementrian Pendidikan dan Kebudayaan RI. (2016). Peraturan Mendikbud tentang Standar Isi Pendidikan Dasar dan Menengah (Permendikbud Nomor 21 tahun 2016). Jakarta: Penulis.

Komariah, K. (2011). Penerapan Model Pembelajaran Problem Solving Model Polya untuk Meningkatkan Kemampuan Pemecahan Masalah Bagi Siswa Kelas IX J di SMPN 3 Cimahi. Prosiding Seminar Nasional Penelitian, Pendidikan dan Penerapan MIPA. Diunduh dari: http://eprints.uny.ac.id/7195/

Porwanto, M. (2014) Analisis Kesalahan Siswa dalam Menyelesaikan Masalah Matematika Bentuk Soal Cerita Pada Pokok Bahasan Peluang SMA Tribhakti Tanggulangin Kelas XII IPS. Sidoarjo. Jurnal Pendidikan Matematika STKIP PGRI Sidoarjo Vol.2, No.1 ISSN: 2337-8166

Purnamasari, P.D. (2015). Analisis Kemampuan Pemecahan Masalah Matematika Siswa Kelas XI SMK Muhammadiyah I Patuk Pada Pokok Bahasan Peluang. Yogyakarta. Jurnal Pendidikan Matematika dan Sains.

Republika. (2018). Pentingnya Belajar Pemecahan Masalah di Matematika. Bogor. Diakses dari https://www.m.republika.co.id pada Selasa, 24 September 2019

Romika \& Amalia,Y.(2014). Analisis Kemampuan Pemecahan Masalah Matematika Siswa Pada Materi Bangun Ruang Sisi Datar dengan Teori Van Hiele. Aceh. Jurnal Binagogik Vol.1 No.2

Suci, A.A.W. \& Rosyidi, A.H. (2012). Kemampuan Pemecahan Masalah Matematika Siswa Pada Pembelajaran Problem Posing Berkelompok. MATHEdunesa, 1(2)

Sumartini, T.S. (2016). Peningkatan Kemampuan Pemecahan Masalah Matematis Siswa melalui Pembelajaran Berbasis Masalah. Garut. Jurnal "Mosharafa", Vol.5, No.2 ISSN 20864280 